\title{
THE ROLE OF THE DANUBE SWABIANS IN THE HISTORY OF THE SERBS: A HETERODOX VIEW*
}

\begin{abstract}
The paper deals with the overall influence of the Danube Swabians, i.e., the Vojvodina Germans on the Serbs and their history. It deals with modes of contact and their significance.
\end{abstract}

Key words: Serbs, Germans, Danube Swabians, Vojvodina, WWII

The Serbs and the Germans had never been neighbors in the real sense of the word, but throughout large part of history they had been in steady contact. Sometimes it was direct, although in those cases it did not involve larger numbers of the two peoples. However, the importance of these contacts always surpassed the sheer number of people actually making them. Thus for instance Saxon miners from Transylvania came to Serbia after 1240 and developed the mining industry that, according to some historians, was the main economic pillar of the medieval Serbian state, i.e. the branch of the economy that made possible the rise of the Nemanjić state. The Saxons brought along mining technology and expert terminology that survived long after the Saxon miners had disappeared. They also brought the make-up of autonomous towns modeled on towns in Germany. All these were important novelties in medieval Serbia and the agents who had introduced them were few in number. It is not known what eventually happened to these Saxon miners: maybe they were assimilated by the locals over time, or maybe they moved away before the Ottoman expansion. ${ }^{1}$ To this day there are place-names in Serbia and Bosnia reminiscent of their fruitful stay. The influence of German mercenaries serving Serbian rulers (Czar Dušan for instance) was certainly much smaller, although a larger number of historical sources (that unfortunately are not very likely to emerge) would probably bring about new discoveries in that respect. ${ }^{2}$

\footnotetext{
* This article has been written within the framework of the scholarly project Serbs and Serbia in the Yugoslav and International Context: Internal Development and Position within European/ World Community (№ 47027), financed by the Minisry of Education, Science and Technological Development Republic of Serbia.

1 Stojan Novaković, Novo Brdo i Vranjsko Pomoravlje u istoriji srpskoj XIV i XV veka, Godišnjica Nikole Čupića, III, 1879, pp. 280-294; Mihajlo J. Dinić, Za istoriju rudarstva u srednjevekovnoj Srbiji i Bosni, I, Beograd, 1955, pp. 1-27; Sima M. Ćirković, Srbi među evropskim narodima, Beograd, 2004, pp. 58-59; Istorija srpskog naroda (henceforth: ISN), I, Beograd, 1981, pp. 345348, 369-371, 385-386, 471, 539.

2 Maybe it would be proven that some typical Western achievements came to Serbia (also) through foreign mercenaries. (ISN, I, p. 506; Zoran Konstantinović, Deutsch-serbische Begegnungen, Berlin 1997, p. 29)
} 
After the fall of the medieval Serbian state, apart from occasional travelers, direct contacts with the Germans were probably reduced mostly to contacts with the Habsburg officers in the Military Border that was gradually set up since 16th century. The contact became more frequent during the Viennese War (1683-1699) and the Great Migration of the Serbs that took place in the course of the war (1689/90). The Viennese War that ended the 150-years long Ottoman rule was fateful for the middle Danube basin, but the Great Migration of the Serbs was even more fateful for the history of the Serbs. ${ }^{3}$ Although the Serbs had lived in the territory of Southern Hungary ever since they had come to this part of Europe, ${ }^{4}$ and although their number increased during 15 th and 16 th centuries, ${ }^{5}$ the importance of the Great Migration cannot be overestimated. It is not only that the number of the Serbs in Hungary increased. ${ }^{6}$ For the first time in history the Serbs were granted imperial privileges recognizing them, not as a historical people of the same rank as the Germans or the Hungarians, but at least as an organized entity that could rightfully demand certain rights and privileges to which completely "unhistorical" peoples of the Monarchy (such as the Romanians, Slovaks, Ruthenians etc.) could never aspire. ${ }^{7}$ These privileges enabled the Serbs to survive as an ethnic community throughout the subsequent centuries, despite the losses through assimilation, conversion to RomanCatholicism and emigration. At the same time, the spread of the Habsburg power to Southern Hungary would enable the re-integration of these part into the Central European cultural sphere, whereas the economic development of the hereditary Austrian lands would eventually spill over to these parts. Thus, the part of the Serbian people that found themselves under the Habsburg rule were able to reconnect to the European civilization with which relations were severed by the Ottoman conquest in 15 th century. It also enabled them to be integrated into an economy that albeit comparatively belatedly, started to modernize. Gradual economic and cultural rise of the Serbs in Southern Hungary would have

3 About it and its significance: Dušan J. Popović, Velika seoba Srba, Beograd, 1954; Idem, Srbi u Vojvodini, I. Od najstarijih vremena do Karlovačkog mira 1699, Novi Sad, 1990. (2nd ed.), pp. 328-335; Stefan Čakić, Velika seoba Srba 1689/90. i patrijarh Arsenije III Crnojević, Novi Sad, 1982; ISN, III/1, Beograd, 1993, pp. 506-553; Olga Zirojević, Srbija pod turskom vlašću 14591804, Beograd, 2007, pp. 169-190; Ćirković, pp. 148-152.

4 Popović, Srbi u Vojvodini, I, pp. 37-43; ISN, I, pp. 122-123, 157; Yovan Radonitch, Histoire des Serbes en Hongrie, Paris, Barcelona, Dublin, 1919, pp. 6-14; Mita Klicin, Kratka istorija srpskog Elzasa od VI-XX. veka, Beograd, s. a., pp. 5-9; Aleksa Ivić, Istorija Srba u Vojvodini (od najstarijih vremena do osnivanja Potisko-pomoriške granice (1703)), Novi Sad, 1929, pp. 5-6.

5 ISN, II, Beograd, 1982, pp. 248-267; 315-389, 413-490; Popović, Srbi u Vojvodini, I, pp. 74-109, 171-173, 205-213; Radonitch, pp. 30-81; Ivić, pp. 7-187; Klicin, pp. 10-17.

6 During the Ottoman rule and immediately after it the Serbs even made up the majority of the population in the liberated territories. (Radonitch, pp. 81-85, 99; Klicin, pp. 20; Radivoj Simonović, Etnografski pregled Vojvodine, Novi Sad, 1924, p. 9; Gerhard Seewann, Serbische Süd-Nord-Migrationen in Südosteuropa als Voraussetzung für die deutsche Ansiedlung im 18. Jahrhundert, in: A Kárpát-medence vonzásában, Pécs, 2001, p. 429.)

7 Čakić, pp. 214-222, 279-323; Popović, Srbi u Vojvodini, I, pp. 328-345; Ibid., II. Od Karlovačkog mira 1699. do Temišvarskog sabora 1790, pp. 55-57, 191-228; ISN, IV/1, Beograd, 1986, pp. 41-57; Dimitrije Đorđević, Die Serben, in: Adam Wandruszka, Peter Urbanitsch (eds), Die Habsburger Monarchie 1848-1918, III/1, Wien, 1980, pp. 734-774; Fran Zwitter, Jaroslav Šidak, Vaso Bogdanov, Les problems nationaux dans la Monarchie des Habsbourg, Belgrade, 1960, p. 29. 
beneficial influence on the development of the main mass of the Serbian people living in Serbia in 19th century.

Two factors were decisive for the transfer of achievements of modern European civilization to the Serbs in Hungary. The first was that the Habsburg government as such, strove to introduce modernizing measures in that part of its territory - according to the contemporary conceptions, its abilities and needs. The other factor was the Danube Swabians who were at the same time, both the tool and the object of these modernizing measures.

The name Danube Swabians was created by geographers only in 1920s as a designation for descendents of German colonists of various ethnic backgrounds. ${ }^{8}$ The Serbs, as well as other peoples of the region, called them simply Swabians - as indeed they themselves referred to their ethnic group. Although their ethno genesis was completed only in 20th century, they had always been perceived as a whole by the Serbs and members of other peoples. Furthermore, among achievements of civilization, objects of material and spiritual culture, language influences and other novelties that the Serbs were encountering in their contacts with the Habsburg state and German colonists, the Serbs were often not able to differentiate between the influences stemming from the authorities and those coming from the Swabians themselves. They also could not distinguish between things that were genuinely Swabian (very conditionally speaking) and achievements that had been only transferred to the Serbs and other peoples through Swabian colonists' mediation. ${ }^{9}$

In this paper we will not deal with the things that the Serbs from Southern Hungary took over form their Swabian neighbors or vice versa, ${ }^{10}$ but rather with the role the Danube Swabians had played in the history of the Serbs - not only in Southern Hungary, but also in Slavonia, Bosnia and Serbia itself. We shall explore various kinds of influences and their importance, placing them whenever necessary into a broader context of Serbian-German relations.

On initial consideration it is clear that the Swabians were of much larger importance for the Serbs in Vojvodina, and the Serbs in general, than the Serbs for the Germans. Due to the difference in number, economic and cultural development this is no wonder: the Germans had always been an important factor for the Serbs, whereas vice versa held true only for exceptional, as a rule conflicting historical junctures, and even then not for long.

The settlement of German colonists in Southern Hungary was part of the Habsburg strategic policy of military and economic strengthening of the newly-

8 The name was coined by the Stuttgart geographer Hermann Rüdiger in 1922. in order to designate the Germans living in the territory of the historic Kingdom of Hungary who were not Transylvanian Saxons. (Cf. Leidensweg der Deutschen im kommunistischen Jugoslawien, II. Erlebnisberichte über die Verbrechen an den Deutschen durch das Tito-Regime in der Zeit von 1944-1948, München, Sindelfingen, 1993, p. 16.)

9 Cf. Zoran Janjetović, Gegenseitige Kultureinflüsse zwischen Serben und Donauschwaben in der Vojvodina, Jahrbuch für deutsche und osteuropäische Volkskunde, 50, 2008/2009, pp. 103-133.

10 More about that and about the things the Swabians took over from the Serbs in: Janjetović, Gegenseitige Kultureinflüsse; Idem, Srpski uticaj na svakodnevnu kulturu Nemaca u Vojvodini, Godišnjak za društvenu istoriju, XVI, 2, 2009, pp. 19-32; Idem, Neprolazna svakodnevica: Nemački doprinos narodnoj kulturi Vojvodine, Tokovi istorije, 3-4, 2008, pp. 214-223; Zlatoje Martinov, Nemački uticaj na ishranu Srba u Banatu, Pančevo, 2004. (2nd ed.); Nives Rittig-Beljak, Švapski kulinarij - dodir tradicija u Hrvatskoj, Zagreb, 2002. 
acquired territories. The colonization of the Germans was motivated above all by economic reasons: German peasants were obedient, hard-working, comparatively modern in their working methods and Roman-Catholics (which was up to 1780 one of the primary conditions of eligibility). ${ }^{11}$ As such it influenced the political and ethnic make-up of the region in the long run. At first it damaged the existing economic structure and the way of life, particularly of the Serbian population that was the most numerous after the end of the Ottoman rule. After the collapse of the medieval Serbian state, the Serbian population turned to a large extent from agriculture to cattle-breading that offered better surviving possibilities under Ottoman rule. ${ }^{12}$ It made possible speedy withdrawal before the approaching Ottoman armies or punitive expeditions, crossing from the Turkish to Habsburg territory and vice versa, quick acquisition of livelihood by robbing cattle belonging to other clans and tribes, migration to more fertile, friendlier and safer areas etc. Cattle-raising was thus the most convenient form of economy for a population that was constantly forced to move. ${ }^{13}$ This economic model was transplanted to Southern Hungary too, and after the Great Migration of the Serbs in 1690 it became the dominant mode of economic life in that region: the Ottoman power disappeared together with substantial portion of the population, the new authorities had not yet consolidated and the land was still not returned to the old, or given to new private owners. As the situation in the newly-liberated areas started to normalize, i.e. when the social and economic regime similar to the one in other Habsburg lands started to be established, the semi-nomadic and cattle-breading way of life of the Serbs became increasingly threatened. ${ }^{14}$

Colonization of peasants of different ethnic background was the main means the authorities and landowners employed in order to increase the number of inhabitants, and consequently, revenues from the newly acquired areas. However, this also proved to be the main means for the destruction of the Serbian way of life, while the German colonists were the main proponents of the new, predominantly land-tilling way of life. This coupled with the obligation to till the land and build houses for the newcomers and to pay taxes, from which the colonists were exempted for a while, spurred the Serbs to attack the colonists

11 Seewann, pp. 421-442; Oskar Feldtänzer, Georg Wildmann, Donauschwäbische Geschichte, I. Das Jahrhundert der Ansiedlung 1689-1805, München, 2006; Márta Fata, Einwanderung und Ansiedlung der Deutschen (1686-1790), Günter Schödl (ed.), Deutsche Geschichte im Osten Europas. Land an der Donau, Berlin, 1995, pp. 90-196; Konrad Schünemann, Österreichs Bevölkerungspolitik unter Maria Theresia, I, München, 1935; Sonja Jordan, Die kaiserliche Wirtschaftspolitik im Banat im 18. Jahrhundert, München, 1967; Imre Wellmann, Die erste Epoche der Neubesiedlung Ungarns nach der Türkenzeit (1711-1761), Acta historica, XXVI, 1980, pp. 241-304. The Serbs, on the other hand, being tough border soldiers, were settled primarily for military reasons.

12 In some South Slav dialects cattle is still called „blago“ i.e. „treasure“.

13 Jovan Cvijić, Balkansko poluostrvo i južnoslovenske zemlje. Osnovi antropogeografije, Beograd, 1966, pp. 128-156; Seewann, p. 421; Ćirković, p. 124; Radonitch, p. 99.

14 This does not mean the Serbs did not engage in land-tilling. On the contrary: it was the activity they engaged in ever since their settlement in the Balkans, but under the changed conditions it became only a subsidiary branch of the economy. In the Balkan mountains where a large part of the population saught refuge before the Ottoman invasion, it could not have developed much anyway due to the characteristics of the soil. 
on several occasions. ${ }^{15}$ Contrary to the claims of some Serbian nationalists, the aim was not to destroy the compact Serbian settlement: ${ }^{16}$ it never existed due to the small number of Serbs and presence of members of other nationalities on the territory as a whole, and the colonization was implemented for economic reasons. ${ }^{17}$ It was organized by secular and ecclesiastical authorities, as well as by numerous private landowners who needed the labor force. The colonists themselves had little say in the choice of the place they were going to colonize, the way of their colonization, the way houses and villages were built, or the way land was tilled: in most cases all these things were decided by the authorities. However, it was the settlers who turned the orders of the authorities into practice. Thus, the rage of the Serbs who were hit by the change of the economic structure, impounding of pastures and fields (and sometimes even of houses) and destruction of their way of life was directed at the Swabians and not at the authorities who were behind them. ${ }^{18}$ On the one hand, the authorities were less visible, and on the other, stronger than the colonist families.

Afterwards, some Serbian authors tended to see only the bad consequences of the colonization for the Serbs - in the first place the facts that the Serbs had lost land and that their share in the overall population was constantly declining. Some of them overlooked not only the fact that large Serbian landowners also colonized peasants of other nationalities, including the Germans, but also that due to their spendthrift habits the Serbs themselves were to blame for losing land to the more diligent and thriftier Swabians later on. ${ }^{19}$ Some of them also overlooked the large importance of German colonization for cultivation of Southern Hungary and her

15 Seewann, pp. 433, 436. By far not all German were colonist farmers. There was a considerable number of war veterans, artisans, advenutrers and some deported convicts among them, especially in the begining. Contrary to the claims of some anti-German authors, the last mentioned were never very numerous, and most of them used the first opportunity to return to their Austrian homeland. (Cf. Schünemann, pp. 76-88; Wellmann, pp. 268)

16 This view influenced a part of scholarly writings. (Klicin, p. 21; Toša Iskruljev, O Vojvodini i njenoj kolonizaciji, Novi Sad, 1925, pp. 11, 28; Mirko Mitrović, Naseljavanje i kolonizacija Vojvodine 1690-1945, Godišnjak Društva istoričara SAP Vojvodine, 1984, p. 202; ISN, IV/1, p. 214; Branislav Bukurov, Naselja u južnom Banatu, Zbornik Matice srpske za prirodne nauke, 39, 1970, p. 30; Vera Milutinović, Nemci u Vojvodini, Etnološki pregled, 4, 1962, p. 36) The first two authors here quoted should be seen as quite nationalistic.

17 It is impossible to say what the Habsburg policy would have been had the number of Serbs and the density of their settlement been much larger.

18 Erik Roth, Die planmäßig angelegte Siedlung im Deutsch-Banater Militärbezirk 1765-1831, München, 1988, pp. 45, 51; Felix Milleker, Geschichte der Banater Militärgrenze 1764-1873, Pančevo, 1925, pp. 41-42; Idem, Die Besiedlung der Banater Militärgrenze, Bela Crkva, 1926, p. 5; Borislav Jankulov, Pregled kolonizacije Vojvodine u XVIII i XIX veku, Novi Sad, 1961, pp. 26-27, 30, 34.

19 Gavrilović, p. 15; Idem, Privredne i društvene prilike u Inđiji 1746-1849, Godišnjak Filozofskog fakulteta u Novom Sadu, 6, 1961, p. 157; ISN, IV/1, p. 214; Radoslav Marković, Pravoslavna srpska parohija u Inđiji krajem 1900. godine, Inđija, 1997, (reprint), p. 22; Vasilije Kolaković, Naselje Ovča, Godišnjak grada Beograda, VII, 1960, p. 122; C. A. Macartney, Hungary and Her Successors. The Treaty of Trianon and its Consequences 1919-1937, London, New York, Toronto, 1937, p. 34. The nationalist Iskruljev also realized the reasons why the Serbs had lost land in favor of the Germans. (Cf. Toša Iskruljev, Raspeće srpskog naroda u Sremu 1914. godine i Madžari. Sa madžarske granice. Bajski trokut. Sent Andreja, Novi Sad, 1936, pp. 306-309, 327) 
economic development. ${ }^{20}$ They did as nationalists usually do: they saw only one side of the coin. They wanted Vojvodina ${ }^{21}$ (i.e. former Southern Hungary) to be predominantly Serbian and at the same time to remain the best developed territory inhabited by the Serbs. Once the ethnic predominance was finally achieved after WWII, it would happen at the expense of an economic and cultural decline, as will be shown briefly.

Having come to (predominantly) Serbian environment in Bacska, Baranya ${ }^{22}$ and Western Banat, the ancestors of the Danube Swabians brought a completely new element into Serbian history. Not only ethnic, but above all cultural. Throughout their history in the Balkans, the Serbs got used to living in contact with other peoples. However, these peoples were mostly (often despite religious differences) either ethnically related to them (the Croats, Bulgarians, Ragusans), or belonged more or less to the same Balkan-Ottoman-Oriental cultural sphere. In other words, they were different, but not completely alien. ${ }^{23}$ The Hungarians with whom the Serbs had been living together under Ottoman rule and partly already since the Middle Ages, and particularly the Romanians who were also Orthodox and predominantly mountain shepherds, did not differ from the Serbs in customs, way of life and culture as much as the German colonists of various ethnic backgrounds who were truly foreign. To make matters worse, in language, religion, customs and other characteristics, they were akin to representatives of the unloved Habsburg authorities. In contact with them the Serbs of Southern Hungary had to learn how to live beside someone who was completely different. This is the lesson human beings, in general, have difficulty mastering. During two odd centuries of life in the neighborhood of the Swabians, the Serbs learned to respect them, to live peacefully with them and to cooperate with them occasionally, but it seems real intimacy between members of the two peoples never developed. Reasons for great differences still existed but in the second half of 19th century they were no longer so much in the way of life, but rather in interests and mentality. ${ }^{24}$

20 Unlike some other authors Slavko Gavrilović even claims South Hungary was economicaly the best developed part of Hungary in 1848. (Slavko Gavrilović, Srem, Banat i Bačka od kraja XVIII do sredine XIX veka, Zbornik za istoriju, 6, 1972, p. 17.) On the other hand, some Danube Swabian authors overestressed the importance of Swabian colonists, disregarding numerous measures taken by the authorities and landowners, as well as the contribution of other ethnic groups to the economic development of Hungary.

21 The notion of Vojvodina changed its meaning over time. Conceived as an autonomous Serbian territory in Southern Hungary, Vojvodina was established briefly for the first time after the revolution of 1848/49. Even then it existed more on paper than in reality. Later on it became synonimous with the Bacska, the Banat and Baranya (especialy their parts that became part of the Kingdom of the Serbs, Croats and Slovenes after 1918). After WWII the Autonomous Province of Vojvodina comprized Eastern Syrmium, Bacska and the Yugoslav part of the Banat, but no longer the Yugoslav part of Baranya. (Cf. Edgar Hösch, Karl Nehring, Holm Sundhaussen (eds.), Lexikon zur Geschichte Südosteuropas, Wien, Köln, Weimar, 2004, pp. 733-734) We shall deal mostly with the territory of Vojvodina as defined after 1945 .

22 Considerable number of Serbs also lived in Baranya in early 18th century, as well as in parts of Banat that do not belong to the present-day Republic of Serbia.

23 A number of features that laymen consider typically „Serbian“ (such as numerous dishes, music, costume, words etc.) are in fact of Oriental, Arabic and Persian origin and were brought to Serbia by the Ottomans.

24 It is interesting to note that the relations of the Serbs with the Magyars have always been more emotional: when they were bad, it led to great bloodsheds, and when they 
The Danube Swabians came to Hungary propelled by natural human desire to achieve a better living. After many decades and several generations most of them managed to secure a comparatively decent living. Realizing that the German way of production was more profitable, members of other ethnic groups, including the Serbs, have adopted it. However, the differences in mentality that still exist to a large extent remained: whereas the Germans are mostly practical, realistic materialists, the Serbs are mostly temperamental and often national idealists. The Serbs adopted the German way of tilling land, German dress, cuisine etc., but in most cases not the German thriftiness and sobriety. ${ }^{25}$ These characteristics enabled the Swabians to enlarge their landownership at the expense of the Serbs and members of other ethnic groups. Thus the difference in mentality led to a difference in economic interests. When available arable land became scarce in Bacska and Banat in the second half of 19th century, parts of the Swabians started emigrating to Syrmium and Slavonia. There they were able to buy much larger plots of land than in Southern Hungary for the same amount of money. The ones who sold the land were the Serbs and the Croats who were pauperized due to improvident living, spread of capitalism and break-up of large family communities after the Military Border had been disbanded. Differences of mentality combined with these factors led to animosity here too: in a way, the Swabian newcomers, together with the Jews, were the symbol of the evils of modernization with which the patriarchal Serbian (and Croatian) society could not cope. ${ }^{26}$ Similar situation, although on smaller scale, reoccurred in Bosnia after 1878 where a smaller number

were good to much greater intimacy. It was recorded during the inter-war period that the Serbs and the Hungarians adressed each other as „brother“, whereas they adressed the Germans only as „neighbor“. (Cf. Zoran Janjetović, Deca careva, pastorčad kraljeva. Nacionalne manjine u Jugoslaviji 1918-1941, Beograd 2005, p. 90.) On the Swabian mentality cf. Zoran Janjetović, Duhovni profil vojvođanskih Švaba, Tokovi istorije, 1-2, Beograd, 2000, pp. 55-67.

25 Marković, Pravoslavna srpska parohija, passim; Idem, 0 raskošu (modi) i ostalim štetnim običajima i navikama našim, Zagreb 1905; Idem, Sadašnje stanje naše agrarne privrede (prilog k temi da li naš narod propada), Letopis Matice srpske, 286, 1912, pp. 46, 50; Popović, Srbi u Vojvodini, II, pp. 33-34; Mariann Nagy, Nineteent Century Hungarian Authors on Hungary’s Ethnic Minorities, László Kontler (ed.), Pride and Prejudice. National Stereotypes in 19th and 20th Century Europe East to West, Budapest, 1995, pp. 42-43; Leonhard Böhm, Geschichte des Temeser Banats, I, Leipzig, 1861, pp. 214-215; Ibid, II, pp. 205-211, 217; Paul Hunfalvy, Ethnographie von Ungarn, Budapest, 1877.

26 Milan Šenoa, Doseljavanje tuđinaca u Srijem, Rad JAZU, knj. 201, reazred historičko filologički i filozofičko juridički, 1914, pp. 1-13; Valentin Oberkersch, Die Deutschen in Syrmien, Slawonien und Kroatien bis zum Ende des Ersten Weltkrieges, Stuttgart, 1972, pp. 22-41; Hermann Haller, Die Entstehung der deutschen Tochtersiedlungen in Syrmien, Der Auslanddeutsche, XX, 4, 1937; Georg Wild, Deutsche Siedelungen in Syrmien, Slawonien und Bosnien, Südostdeutsches Archiv, XIV, 1971; Holm Sundhaussen, Die Deutschen in Kroatien-Slawonien und Jugoslawien, Schödl (ed.), pp. 309-314; E. Meynen (ed.), Das Deutschtum in Slawonien und Syrmien. Landes- und Volkskunde, Leipzig 1942. The relations between the Germans and the Croats was made easier thanks to the common Roman-Catholic church that also made assimilation of the Germans with the Croats easier. In the case of the Serbs the difference in religion was yet another insurmountable obstacle. (Carl Bethke, Deutsche und ungarische Minderheiten in Kroatien und der Vojvodina 1918-1941. Identitätsenwürfe und ethnopolitische Mobilisierung, Wiesbaden, 2009, pp. 106-114) 
of the Vojvodina Germans sought fortune. ${ }^{27}$ In Syrmium and Slavonia those Serbian and Croatian circles that sought cooperation on the grounds of ethnic similarity and opposition to the Hungarians were additionally pushed together by immigration of German and other foreign peasants. Thus, the Danube Swabians also made a small but direct contribution to the development of the Yugoslav idea that - as every national idea - needed a real or imagined foe in order to close ranks of its adherents. ${ }^{28}$

This, however, was just one of the roles the Vojvodina Germans played in Serbian history. The Danube Swabians from South Hungary were, together with their Serbian fellow-countrymen, important agents of modernization in liberated Serbia after 1830s. There were no peasants among them, but there were many artisans (particularly those making new, modern handicrafts), workers and innkeepers. ${ }^{29}$ Together with members of other nationalities, penetration of foreign capital, importation of goods, education of large number of local young men at German and Austrian universities, they became a factor of Serbia's modernization in 19 th and early 20 th centuries ${ }^{30}$ Surly, it would be impossible to separate their influence from that of other factors.

However, what is obvious is a comparatively slow and incomplete modernization of the Serbian society. It comprised towns in the first place (particularly Belgrade) and especially upper classes. ${ }^{31}$ Huge masses of peasantry remained for a long time illiterate, badly connected with domestic and international market, devoted to old customs and way of life. For them the adjective "Swabian" (meaning "German") continued to signify everything that was foreign and alien. Because a common man more often experienced the bad than the good sides of modernization, the "Swabian" influence was also perceived more as bad than as good, and a "Swabian" - even if he was a Vojvodina German who spoke perfect Serbian, and even if his achievements deserved respect - remained the paragon

27 More than one half of colonists belonged to other nationalities there and the share of the Vojvodina Swabians was quite small. Colonization of those territories was partly state-sponsored, which, among other things, made the colonists particularly unpopular with the local nationalists. Despite that, difficult living conditions in several places brought German colonists and local Serbian peasants closer. It seems the Serbs got along better with the Protestants. (Tomislav Kraljačić, Kolonizacija stranih seljaka u Bosnu i Hercegovinu za vrijeme austrougarske uprave, Istorijski časopis, knj. XXXVI, 1989; Ferdo Hauptmann, Regulisanje zemljišnog posijeda u Bosni i Hercegovini i počeci naseljavanja stranih seljaka u doba austrougarske vladavine, Godišnjak Društva istoričara Bosne i Hercegovine, XVI, 1965; Dušan Drljača, Kolonizacija i život Poljaka u jugoslovenskim zemljama. Od kraja XIX do polovine XX veka, Beograd, 1985; Hans Maier, Deutsche Siedlungen in Bosnien, Stuttgart, 1924; J. Heimfelsen, Die deutschen Kolonien in Bosnien, Wien 1911; Fritz Hoffmann, Josef Zorn (ed.), Franz-Josefsfeld - Scönborn. Geschichte einer deutschen Gemeinde in Bosnien, Freilassing 1963)

28 Ернст Гелнер, Нациите и национализмот, Скопје, 2001, pp. 85-92.

29 ISN, VI/1, Beograd 1983, pp. 10-31; Christian Brücker, Deutsche Spuren in Belgrad, Belgrad, 1944.

30 As a representative (to be sure, way above the average!) of those enterprising Swabians one can mention Đorđe Vajfert (Georg Weifert), enterpreneur, industrialist, business-man and patron of arts who ended his careere as governer of the National Bank of the Kingdom of the Serbs, Croats and Slovenes. (Saša Ilić, Sonja Jerković, Vladimir Bulajić, Đorđe Vajfert, Vizionar i pregalac. Lična i poslovna ilustrovana biografija (1850-1937), Beograd, 2010)

31 Marie Janin Calic, Sozialgeschichte Serbiens 1815-1941. Der aufhaltsame Fortschritt während der Industrialisierung , München, 1994. 
of otherness, invoking considerable amount of negative sentiments. Furthermore, the Vojvodina Serbs who came to Serbia to make careers as teachers, professors, doctors and civil servants were also included into this stereotype. They were often equated with the Germans and derogatory called "the Swabians". ${ }^{2}$ Probably it was this unwilling respect before the achievements of others, certainly combined with other factors (the main being Austro-Hungarian policy towards Serbia and the position of Serbs within the Monarchy) that bred the feeling of insecurity or even threat. For the Serbs in Vojvodina and in Slavonia it was complemented by the undisputed fact that the Danube Swabians presented dangerous economic competition. Furthermore, because of the propensity of a large number of wealthier and better educated Swabians to become Magyarized for purposes of social climbing, and because of open sympathies of the unassimilated Swabians for the Hungarians and the Hungarian state idea, nationally conscious Serbs in the Habsburg Monarchy tended to see the Swabians the "auxiliaries" of the otherwise insufficiently numerous Magyars. ${ }^{33}$

The creation of the Kingdom of the Serbs, Croats and Slovenes in the fall of 1918 forced the Serbian elites to change their attitude towards the Germans in Vojvodina. They were no longer perceived as a mainstay of foreign power, but they still had not become the pillar of the Yugoslav one. They were yet to be won over to the new state and its leading people, the Serbs. ${ }^{34}$ This held true especially for the interregnum - from the Belgrade armistice of November 13, 1918 until the signing of the Trianon Peace Treaty on June 20, 1920 that definitively allocated Vojvodina to the Kingdom of the SCS. During the first couple of years it seemed that the Germans (at least those in Vojvodina) would be treated better than other national minorities. ${ }^{35}$ Soon it turned out that that it would be impossible. There were several hurdles: the Germans could not be given (much) more than other minorities because these would demand the same (particularly the Hungarians and the Albanians who, due to their irredentist tendencies, were viewed as particularly irksome). Serbian politicians and "national workers" were not able to overcome

32 Petar Krestić, „Švabe ili Nemačkari“, Zbornik Matice srpske za istoriju, 49, 1994, pp. 31-43; ISN, VI/1, Beograd 1983, pp. 10-31; Andrej Mitrović, Srbi o Nemcima. Jedno „viđenje drugog“ stvoreno istorijom, Milorad Sofronijević, Miodrag Maksimović (eds), Srbi o Nemcima, Beograd, 1996, pp. 11-16.

33 On Magyarization of the Germans in Hungary cf. Johann Weidlein, Madjarisierung der Deutschen in Ungarn, Schorndorf ,1955; Ingomar Senz, Donauschwäbische Geschichte. Wirtschaftliche Autarchie und politische Entfremdung 1806-1918, München, 1997, pp. 191-224, 287-314, 353358; Idem, Die nationale Bewegung der ungarländischen Deutschen vor dem Ersten Weltkrieg, München, 1977, pp. 16-30.

34 During the last few decades of the existence of Austria-Hungary there were several sporadic attempts at cooperation between Serbian politicians in Vojvodina and nationaly conscious leaders of the Danube Swabians. (Senz, Die nationale Bewegung, pp. 185, 245-247; Arpad Lebl, Građanske partije u Vojvodini 1887-1918, Novi Sad, 1979, pp. 88,118) The problem was that the large majority of the Swabians was under strong Hungarian cultural and political influence, and part of them had already been assimilated into Magyars.

35 Janjetović, Deca careva, pp. 128-130, 228-229, 292-293; Toma Milenković, Banatska republika i mađarski komesarijat u Banatu (21. oktobar 1918-20. februar 1919), Zbornik Matice srtpske za istoriju, 32, 1985, p. 136; Andrea Schmidt-Rösler, Rumänien nach dem Ersten Welttkrieg: Die Grenzziehung in der Dobrudscha und im Banat und die Friedensprobleme, Frankfurt, 1994, pp. $210,254$. 
their own nationalism. They believed that Vojvodina could be "nationalized" mostly by the same methods the Hungarian authorities had been using with mean results for decades: schools, imposition of the official language, economic discrimination, colonization of their own co-nationals. ${ }^{36}$ Furthermore, because of Croatian and particularly Slovenian partners in power, ${ }^{37}$ the German minority (that for the greatest part lived intermixed with the Serbs) could not be treated more magnanimously. Therefore, the Swabians became part of what the leftists called „the unsolved national question“. Unfortunately the scope and importance of that matter did not make the Serbian elites realize the need for improving the treatment of members of other nationalities. ${ }^{38}$ Certain privileges that the German minority (mostly in Vojvodina) was granted in $1930 \mathrm{~s}^{39}$ were but a comparatively small concession that came too late. What was most important, they were given for reasons of foreign policy. As such they did not have the inherent possibility of changing the way of thinking of the Serbian leading circles. ${ }^{40}$

The national coming of age of the Vojvodina and Slavonian Swabians took place simultaneously with Nazi accession to power in Germany and this would have tragic consequences for the fate of the Yugoslav Germans. Due to unsatisfactory position of the German minority and the propaganda from the

36 Zoran Janjertović, Nacionalne manjine u očima srpske elite 1918-1941, Srbi i Jugoslavija. Država, društvo, politika, Beograd, 2007, pp. 118-143.

37 After the historical table turning in 1918 nationaly conscious part of Slovenian intelligentsia continued with severe measures the struggle against the local Germans that had been going on ever since mid-19th century. (Arnold Suppan, Zur Lage der Deutschen in Slowenien zwischen 1918-1938, in: Idem, Helmut Rumpler (eds), Geschichte der Deutschen im Bereich des heutigen Slowenien 1848-1941, Wien, München, 1988; Martin Wutte, Oskar Lobmeyr, Die Lage der Minderheiten in Kärnten und in Slowenien, Klagenfurt, 1926; Stefan Karner, Die deutschsprachige Volksgruppe in Slowenien, Klagenfurt, Ljubljana, Wien, 1997, pp. 21-46) In Croatia, where the Swabians were less numerous than in Vojvodina, and scattered, creeping assimilation was taking place. The Croatian elites did not want to interrupt it by granting national concessions. (Bethke, pp. 312-323; Vladimir Geiger, Nijemci u Đakovu i Đakovštini, Zagreb, 2001, pp. 116-125)

38 It is only fair to state that the Serbs could hardly find (in history or in the then Europe) a model of magnanimous solution of the minority question. With the sole exception of Estonia and partly of Czechoslovakia, blind nationalism of the majority nation and its impatient imposition on the rest of the population were the rule both in the second half of 19 th century and during the interwar period. They were also the norm in treatment of Yugoslav national minorities in neighboring countries. This certainly did not encourage a more liberal treatment of minorities in Yugoslavia, especially since in most cases the neighboring countries were the nation-states of peoples living as minorities in Yugoslavia. (Cf. Ewald Ammende (ed.), Nationalitäten in Staaten Europas. Sammlung von Lageberichte, Wien, Leipzig, 1931; Janjetović, Deca careva, pp. 407-435)

39 The concessions conserned primarily education and partly organization of associations. The government made these concessions with the aim of improving relations with Germany. Furthermore, due to the opposition of the Croatian and Slovenian elites, they were implemented mostly in Vojvodina. (Janjetović, Deca careva, pp. 251-254; Josef Volkmar Senz, Das Schulwesen der Donauschwaben in Jugoslawien, München, 1969, pp. 91-100; Das Schicksal der Deutschen in Jugoslawien, Augsburg, 1995, p. 26E; Biljana Šimunović-Bešlin, Prosvetna politka u Dunavskoj banovini (1929-1941), Novi Sad, 2007, pp. 274-275, 279-283, 298-302) On the foreign-policy background cf. Hans-Paul Höpfner, Deutsche Südosteuropapolitik in der Weimarer Republik, Frankfurt/M, Bonn, 1983, pp. $320 \mathrm{ff}$.

40 Quite little is known about views of „ordinary“ Serbs toward their Swabian neighbors. Judging by the Danube Swabian „homeland-books“ peaceful coexistence prevailed on the local level. 
Reich, ${ }^{41}$ larger part of them supported actively or passively Hitler's Germany in WWII. ${ }^{42}$ The 7th SS-Division "Prinz Eugen" was largely composed of the German minority, especially the Banat Swabians. "It is remembered by the Serbian and other Yugoslav inhabitants of Serbia, Bosnia-Herzegovina and Dalmatia for the bloody war-crimes it committed. ${ }^{43}$ Above all, the massacres of the division would be used after WWII by the communist regime as an excuse for the cruel treatment of the members of the German national minority.

This unit, however, was not the only one to commit crimes against the civilian population. They were also committed by other German, and non-German units. ${ }^{44}$ Why then did this particular one become so infamous? The reasons are to be found not only in its crimes - that were nothing unusual in those days - but rather in the fact that it was stronger and more dangerous than other German units

41 Such propaganda and its influence are often described as nazification. It was more noticable in appearance than in the real adoption of tenets of nazi ideology from which individuals took what suited their own personal tastes best. More susceptible to influences from the Reich were the younger and poorer members of the German minority, as well as the Protestants. (Dušan Biber, Nacizem in Nemci v Jugoslaviji 1933-1941, Ljubljana, 1966; Zoran Janjetović, O nacifikaciji vojvođanskih Švaba, Tokovi istorije, 1-4, Beograd 1999, pp. 240-260; Idem, Die Donauschwaben in der Vojvodina und der Nationalsozialismus, in: Mariana Hausleitner, Harald Roth (eds), Der Einfluss von Faschismus und Nationalsozialismus auf Minderheiten Ostmittel- und Südosteuropa, München, 2006, pp. 219-235; Josip Mirnić, Nemci u Bačkoj u Drugom svetskom ratu, Novi Sad, 1974, pp. 36-74)

42 Petar Kačavenda, Nemci u Jugoslaviji 1918-1945, Beograd, 1991, pp. 21-163; Mirnić, pp. 74332; Branislav Popov Miša, Nemački zatvori i koncentracioni logori u Banatu 1941-1944. godine, Beograd, 1992, p. 109; Akiko Shimizu, Die deutsche Okkupation des serbischen Banats 19411944 unter besonderer Berücksichtigung der deutschen Volksgruppe in Jugoslawien, Münster, 2003; Ljubica Šijački, Teror i pljačka okupatora u Banatu 1941-1945. godine, Istraživanja, 7, 1979; Sandor Vegh, Le systéme de pouvoir d'occupation allemand dans le Banat yougoslave 1941-1944, in: Les systémes d'occupation en Yougoslavie 1941-1945, Belgrade, 1963; Ekkehard Völkl, Der Westbanat 1941-1944. Die deutsche, die ungarische und andere Volksgruppen, München, 1991; Z. Krnić, S. Ljubljanović, C. Tomljanović, Neki podaci o organizaciji i radu Njemačke narodne skupine u NDH, Zbornik Historijskog instituta Slavonije, 1, 1963; Antun Miletić, The Volksdeutschers of Bosnia, Slavonia and Srem Regions in the Struggle against the People's Liberation Movement, The Third Reich and Yugoslavia 1933-1945, Belgrade, 1977, pp. 559-603; Zdravko Krnić, The German Volksgruppe in the Independent State of Croatia as an Instrument of German Occupation Policy in Yugoslavia, The Third Reich, pp. 604-621; Josip Mirnić, The Enlistment of Volksdeutschers from the Bačka Region in the Waffen SS, The Third Reich, pp. 622 653; Thomas Casagrande, Die Volksdeutsche SS-Division „Prinz Eugen“. Die Banater Schwaben und nationalsozialistischen Kriegsverbrechen, Frankfurt, 2003; Das Schicksal der Deutschen, pp. 45E-75E.

43 Casagrande, pp. 228-297; Nikica Barić, Ustaše na Jadranu. Uprava Nezavisne Države Hrvatske u jadranskoj Hrvatskoj nakon kapitualcije Kraljevine Italije, Zagreb, 2012, pp. 348-358.

44 Although on the whole the crimes of the „Prinz Eugen“ Division were by no means negligeable, they were no more gross as those of other German divisions (342nd, 704th, 714th, 717th, 113th) that quenched the uprising in Serbia in 1941. (Cf. Venceslav Glišić, Teror i zločini nacističke Nemačke u Srbiji 1941-1944, Beograd, 1970, pp. 41-80; Jovan Marjanović (ed.), Srbija u ratu i revoluciji 1941-1945, Beograd, 1976, passim; Jovan Marjanović, Ustanak i narodnooslobodilački pokret u Srbiji 1941, Beograd, [1963], pp. 120-128, 249-253, 377-390; Valter Manošek, Holokaust u Srbiji. Vojna okupaciona politika i uništavanje Jevreja 1941-1942, Beograd, 2007, pp. 56-61, 64114) As opposed to 20-34.000 of military and civilian victims of the above mentioned divisions in 1941, the „Prinz Eugen“ Division killed less than 1.000 people during its stay in Serbia in 1942. (Cf. Kosta Nikolić, Strah i nada u Srbiji 1941-1944. Svakodnevni život pod okupacijom, Beograd, 2002, pp. 73, 79; Glišić, p. 79.) 
operating in the Yugoslav territory. This was so because unlike the occupational German divisions, it had the normal strength and large number of its members who were not middle-aged reservists as were the soldiers of the occupation divisions from the Reich. Furthermore, it was comprised of people who knew the language and the mentality of the people they were fighting, and partly the territory too. Apart from that, they felt the need to prove themselves as real Germans before their officers from the Reich who looked down on them. ${ }^{45}$ For these reasons they were probably the most dangerous of the numerous partisans' foes. Combined with other acts of collaboration this made it possible to brand the whole German minority as traitors. For the multi-ethnic communist authorities after the war this fact would play a two-fold role.

On the one hand, the behavior of the Volksdeutsche during the war (it did not differ from the other national minorities' pursuit of egoistic national interests or the pursuit of national interest of the majority peoples) served as an excuse for their elimination as an ethnic group. ${ }^{46}$ In that way the new authorities laid their hands on numerous houses and huge tracts of land that were used for rewarding partisan veterans and their families. This was the means of binding a large number of new colonists to the new regime, but it also caused a considerable shortfall in agrarian production due to division of farms and colonization of people who had previously lived in mountainous areas and were unskilled in agriculture. ${ }^{47}$ To be sure, that was also the way to solve one of the most burning social problems of the pre-war Yugoslavia: that of agrarian overpopulation and poverty in economically underdeveloped parts of the country. ${ }^{48}$ On the other hand, in order to justify their cruel treatment of the Germans, the communist painted a completely black picture of the former German minority in public (including historiography). ${ }^{49}$ Allegedly

45 More about it: Casagrande, pp. 187-298.

46 Das Schicksal der Deutschen, pp. 90E-119E, 180E-264E, 197-521, 589-633; Zoran Janjetović, Between Hitler and Tito. The Disappearance of the Vojvodina Germans, Belgrade, 2005, (2nd ed.), pp. 191-301; Michael Portmann, Die kommunistische Revolution in der Vojvodina 1944-1952. Politik, Gesellschaft, Wirtschaft, Kultur, Wien, 2008, pp. 228-267; Vladimir Geiger, Nestanak Folksdojčera, Zagreb 1997; Idem, Pisma iz Krndije, Zagreb, 1994; Idem, Radni logor Valpovo 1945-1946, Osijek, 1998; Idem, Nijemci u Đakovu i Đakovštini, Zagreb, 2001, pp. 171-188; Idem, Ivan Jurković, Što se dogodilo s Folksdojčerima, Zagreb, 1993; Leidensweg der Deutschen im kommunistischen Jugoslawien. Verbrechen an den Deutschen durch das Tito-Regime in der Zeit von 1944-1948, I-IV, Sindelfingen, München, 1991-1994.

47 Nikola Gaćeša, Agrarna reforma u Jugoslaviji 1945-1948, Novi Sad, 1984; Idem, Agrarna reforma u Jugoslaviji (1919-1948), in: Idem, Radovi iz agrarne istorije i demografije, Novi Sad, 1995, pp. 184-195; Portmann, pp. 305-326.

48 German colonization in 18th century helped aleviate the problem of agrarian overpopulation in South-West Germany of the time. Both the Habsburg and the Communist colonizations were basically state-run projects, but the latter was more so. The main difference lies in the fact that the Germans and members of other nationalities were settled into a sparsly inhabited territory where the colonists had to build the infrastructure and move the economy, whereas the colonists after WWII settled in one of the best developed parts of the country. Both Habsburg and Communist authorities achieved their goals by bringing loyal settlers to the area: the Habsburgs political and economic, and the Communists political, social and ethnic.

49 Ljubiša Stojković, Miloš Martić, Nacionalne manjine u Jugoslaviji, Beograd, 1953, pp. 60-62; Kosta Mitrović, Pod kulom vršačkom. Hronologija događaja iz revolucionarnog pokreta Vršca i okoline od 1926. do 1945, Novi Sad, 1969; Žarko Atanacković, Vojvodina u borbi 1941-1945, Novi Sad, 1959; Idem, Srem u Narodnooslobodilačkoj borbi i socijalističkoj revoluciji, Beograd, 
it had already entered the service of the occupiers even before the attack on Yugoslavia, and served them loyally afterwards - although solidarity with the occupiers was often induced by psychological or social pressure, as well as by repression, but also by partisan attacks on Volksdeutsche villages. Although most members of the German minority had sided (emotionally and practically) with the Reich, the picture painted after the war by the Communist authorities was oversimplified and one-sided. ${ }^{50}$ This bad press had another purpose, maybe even more important than the one just mentioned. It served to put the blame for almost the whole collaboration on one single national minority that all but disappeared after the war and thus could not defend itself. ${ }^{51}$ This made it possible to pardon members of all Yugoslav peoples and other national minorities for their disloyal or/and anti-communist behavior during WWII - with only few exceptions who were, as a rule, known by their full names. Thus all the Volksdeutsche were labeled as traitors, but only some individual Serbs (the Chetniks, adherents of Nedic and Ljotić), only some individual Croats (the Ustasha), some individual Slovenes (the White Guard) etc. Thus the myth was created that the Yugoslav peoples, and national minorities as well, ${ }^{52}$ as a whole (with the few above mentioned exceptions) had been good guys, whereas only the Volksdeutsche as a whole (with few honorable exceptions $)^{53}$ had sided with the invaders. This fitted the black and white picture of the war that was spread by the Communist authorities through the media, historiography, schoolbooks, ${ }^{54}$ films, ${ }^{55}$ as well as by the politicians themselves. ${ }^{56}$ It could be said that the Swabians, together with the Germans from

1968; Đorđe Momčilović, Banat u Narodnooslobodilačkom ratu, Beograd, 1977; Branisalv Božović, Juraj Špiler, Zagreb, 1987. See also Yugoslav works from the 1945-1991 period adduced in the footnote 42 .

50 That the picture was far from being just black-and-white was shown comparatively early by the Communist historian Josip Mirnić. (Cf. Mirnić, Nemci u Bačkoj u Drugom svetskom ratu)

51 To be sure, former members of the German minority - often former functionaries - tried in their numerous publications to confute Yugoslav accusations and even to accuse the Yugoslavs (and especially the Serbs) of having committed genocide on the Danube Swabians. However, their works usually did not manage to be heard outside of the expelees' circles so that large section of the public in Germany was not even aware that there had been a German minority in Yugoslavia and what had happened to it. Sometimes this held true for historians too. The best qualified and most fruitful apologist of the behaviour of the German minority in WWII was Johann Wüscht. (Cf. his works: Beitrag zur Geschichte der Deutschen in Jugoslawien für den Zeitraum von 1933 bis 1944, Kehl am Rhein, 1966; Ursachen und Hintergründe des Schicksals der Deutschen in Jugoslawien. Bevölkerungsverluste Jugoslawiens im Zweiten Weltkrieg, Kehl am Rhein, 1966; Die magyarische Okkupation der Batschka 1941-1944, Kehl am Rhein, 1975; Die Ereignisse in Syrmien 1941-1944, Kehl am Rhein, 1975)

52 Cf. for instance Stojković, Martić, pp. 38-63.

53 Slavica Hrečkovski, Njemačka četa „Ernst Thälmann“ u jedinicama NOV i POJ, Zbornik CDISB, 1, 1984, pp. 331-350; Stojanović, Martić, pp. 45-46.

54 Zoran Janjetović, Nemci Jugoslavije u srpskim udžbenicima 1918-2000, Prvi i drugi međunarodni seminar Zajednice Nijemaca u Hrvatskoj 2001./2002., Zagreb, 2002, pp. 125-134.

55 Among films that created negative stereotypes about the Volksdeutsche particular mention deserve TV serials „Salaš u malom ritu“ (1976) (Farm-stead in Mali Rit) and „Zimovanje u Jakobsfeldu“ (1979) (A Winter in Jakobsfeld). To tell the truth, there are several Volksdeutsche who were not shown as bad guys in these sserials.

56 The image of the Volksdeutsche was much more nuanced in literature. (Cf. Vladimir Geiger, Sudbina jugoslavenskih Nijemaca u hrvatskoj i srpskoj književnosti, Zagreb, 2009) 
the Reich were foisted off on the Serbs as the main culprits for Serbian suffering during WWII. This was used to reduce the animosity towards the Croats, whose bad guys, the Ustasha, were joined to the Germans. Hence, the examination of the role of Croatian masses in the war was prevented. Also, it prevented the examination of the role of the Serbs in the war: sympathies of large number of the Serbs for Draža Mihajlović, King Peter II, collaboration with German occupiers, Chetnik slaughters of Muslims in Bosnia-Herzegovina, Partisan slaughters of the Chetniks, and vice versa, etc. In other words, by depicting the Vojvodina Swabians as "Hitlers from our Little Street" 57 the communist authorities precluded many embarrassing questions from being asked. It helped paint an oversimplified picture of WWII in Yugoslavia that was the founding myth of the post-war regime.

Such black and white picture of the war started to dilapidate, together with the socialist socio-economic system in late 1980s. In the context of raising many questions and re-examination of many old established "truths", the interest in the members of the German minority was awakened too. It was manifested firstly in the press and in publicist works, and later on in historiography. A host of articles and several books ${ }^{58}$ contributed to substantial change of image of the Swabians, especially in formerly predominantly Swabian villages. Part of that changed image reached the broader Serbian public. Unfortunately, the turbulent and tragic events in 1990s and economic difficulties in early 21st century diverted most of public attention to other topics. Furthermore, the adherents of the old, biased black perception of the Volksdeutsche are still quite loud. ${ }^{59}$

It can be said that the importance of Germany in the second half of 20th century steadily increased in Serbian eyes - as an economic partner and the destination of the largest Serbian Diaspora - whereas the importance of remembrance of the German minority steadily declined. New generations have grown up who, particularly outside of Vojvodina, have no idea that a large German minority had ever lived in their country. The remnants of this minority itself became active again in 1990s, organizing associations, preserving the language and customs. ${ }^{60}$ However, seen from the outside, it is hard to tell how much all this

57 „Hitler iz našeg sokaka“ was the title of the famous feature film from 1975 directed by Vladimir Tadej.

58 The first books with the new view on the Ethnic-Germans were: Slobodan Maričić, Susedi, dželati, žrtve. Folksdojčeri u Jugoslaviji, Beograd, 1995; Nenad Stefanović, Jedan svet na Dunavu, Beograd 1997. The first supports the old version to a large extent, but enlarges for the first time on the Germans in partisans' ranks and on the suffering of the Ethnic-Germans at the end of the war. Stefanović's book comprizes, apart from the introduction and conclusion by other authors, a number of interviews - testimonies of old Volksdeutsche who had been born in the Vojvodina and who lived in Germany and Austria after WWII. This book marks a watershed in depicting the Vojvodina Swabians in Serbian public. Quite numerous newspaper articles about the Volksdeutsche had different tenors: some repeated old „truths“ and some presented facts until then unknown to the Serbian public.

59 Cf. comparatively numerous letters to the editors that appear every now and then spurred by various causes. Two completely new books that speak about Vojvodina Volksdeutsche in totaly old way have appeared recently. (Cf. Srđan Božović, Divizija „Princ Eugen“, Pančevo, 2011; Goran Babić, Paor s bajonetom. Zločin i kazna vojvođanskih folksdojčera, Beograd, 2012.)

60 Aleksandar Krel, Etnički identitet i položaj nemačke nacionalne manjine u Vojvodini od Drugog svetskog rata do danas, Zavičaj na Dunavu. Suživot Nemaca i Srba u Vojvodini, Novi Sad, 2009. pp. 225-228. 
is spurred by hopes of donations from Germany and how much by sentimental "going back to the roots" like the one experienced by most ethnic groups e.g. in the USA. To what degree persons who declare themselves as Germans in the population census could be regarded as the Danube Swabians, is probably up to ethnologists to decide. Many of these people do not speak a word of German any more, but they have preserved some customs and religious affiliation. For their (broader) environment they are hardly more visible than during the previous decades.

It can be said that, despite their present „invisibility“, the Danube Swabians played an important role in the history of the Serbs, not only in Vojvodina. They were agents of modernization in economy and in material culture for almost two centuries. ${ }^{61}$ They contributed significantly to the economic development of the whole region they inhabited, which influenced the local Serbs too, who for their part, being richer and better educated, could aid the liberation efforts of their conationals in Serbia in early 19th century as well as their efforts to set up a modern state on a European model. Numerous Swabian artisans, workers, entrepreneurs, innkeepers and others also played a role in that. The history of those people remains to be written and the sheer number of Germanisms in everyday speech of those days proves that they deserve it. ${ }^{62}$ In the inter-war Yugoslavia Serbian politicians failed to use the German minority as a two-way bridge connecting the Serbs with one of the largest European nations. Instead, a short-sighted minority policy made it easier for the Nazis to capture the hearts and minds of the Swabians - with tragic consequences, both for the Serbs and the Volksdeutsche. The image of the Volksdeutsche as wartime enemies was probably even more important than their actual help for the war effort of the Third Reich. It served the communists not only to legitimize their harsh treatment of members of the German minority, but also to fortify a simplified view of WWII on the Yugoslav territory in which, allegedly, members of all "peoples and national minorities" fought on the "right side" led by the Communist Party, whereas the occupiers, the Volksdeutsche and not numerous local traitors such as the Chetniks and the Ustasha, fought on the side of Evil. In that way, the Danube Swabians had played an important real and virtual role in Serbian history. Probably the greatest injustice that has befallen on them is that most of the Serbs and the Germans of today are either not aware of their role or have a distorted perception of it.

61 German influences in the sphere of high culture usually went through completely different chanals and not through the predominantly peasant Swabian population.

62 Miloš Trivunac, Nemački uticaji u našem jeziku, Beograd, 1937; Idem, Deutsche Lehnwortforschung im südlsawischen Sprachraum, Belgrad,1941. A large number of Germanisms entered the Serbian language in the Danube Swabian pronunciation or in the Danube Swabian (or Austrian) form that is different from the standard German one. Considerable number of these words disappeared meanwhile, but comparatively many still survive - particularly in the language of the cuisine and of various crafts. 


\section{Резиме}

Др Зоран Јањетовић

\section{Улога подунавских Шваба у историји Срба: један хетеродоксан поглед}

Кључне речи: Срби, Немци, подунавске Швабе, Војводина, Други светски рат

Рад разматра улогу коју су подунавске Швабе, немачки колонисти у Угарској, одиграле у српској историји Војводине, Славоније и Србије. Немачки насељеници, колонизовани да би се од Турака ослобођене територије економски подигле, допринели су уништењу сточарског начина живота Срба у јужној Угарској. Временом су Срби и припадници других народа прихватили немачки начин обраде земље, изградње кућа, кувања, облачења итд., али су остале разлике у менталитету и тежњама. Насупрот немачким штедљивим материјалистима стајали су не много штедљиви српски идеалисти, што је доводило до економског ривалства.

Живот у вишенационалној међуратној југословенској држави није задовољио националне аспирације Шваба, које су у том раздобљу почеле да се буде, што је олакшало продор нацистичких идеја и падање под утицај Хитлерове Немачке. Због тога се током Другог светског рата већина војвођанских Немаца солидарисала с Рајхом, све до злочина. Ово је после рата комунистичким властима омогућило да на бруталан начин уклоне целокупну немачку мањину а на њено место населе лојалне партизанске ветеране из пасивних крајева. И после свог практичног нестанка немачка мањина је играла важну симболичну улогу у пропаганди која је на рачун фолксдојчерског учешћа у рату ублажавала сарадњу с окупатором припадника југословенских народа. 